\title{
Surface engineering of polymers - Case study: PVD coatings on polymers
}

\begin{abstract}
Surface engineering as a subset of materials science is changing the properties of the surface and sub-surface region in a desirable way. A variety of advanced properties like physical, chemical, electrical, magnetic, optical, mechanical, wear-resistant, corrosion-resistant properties at substrate surfaces can be altered by surface modification of materials. The surface chemistry, morphology, and mechanical properties could be important to further adhesion, film formation process and the resulting film properties.

In this work, authors present physical vapour deposition (PVD) as method for surface modification and coating deposition of polymeric materials. The method is clean ecological process that can be managed at once by one filling of PVD chamber. Namely, polymer cleaning, activation, modification of the surface and coating deposition occur consequently one by one process in the same chamber.

Finally, a set of case studies of particular polymers' surface modifications are presented in this work. Plasma team presents its own experience of polymer's modification and coating deposition for targeted applications where basic polymer materials were not eligible to answer the industrial challenges.
\end{abstract}

Key words: surface engineering, physical vapor deposition, polymers

\section{INTRODUCTION}

Materials science is an interdisciplinary field involving the micro and nano-structure, processing, properties of materials and its applications in different areas of engineering, technology and industry. The physical, chemical and mechanical properties of a material surface in most cases determine its applicability in various technical areas. Natural or synthesized materials, metals, ceramics, polymers or composites, sometimes do not possess the proper set of those properties that will allow their direct application. But, surface modified or designed materials at least on their surfaces (on nano- or micronmeter scale) possess an attractive set of properties that is necessary and they can respond to many technical challenges. Therefore, tailoring of the materials' surface is needed in order to meet the applicative requirements.

Novel techniques like surface modification, ion bombardment, self-assembly, coatings, thin film deposition, are developed. Deposition processes and technologies are changing rapidly to keep pace with advanced applications. By their use, a new set of functionality to the material is added to the surface engineered materials such as: reduce

Author's address: ${ }^{1}$ Faculty of Technology and Technical Sciences - Veles, University St. Kliment Ohridski - Bitola, R. Macedonia, ${ }^{2}$ Plasma Doo - Center for plasma technologies, Skopje, R. Macedonia

Received for Publication: 20. 10. 2013.

Accepted for Publication: 26. 12. 2013. costs, performance that does not exist in the bulk mass like, metal properties on the non-metallic surface, or ceramic appearance on metals, etc... Characterization techniques are also improving from day to day.

Surface treatment enhance and improve performance of the bulk material, provides manufacturing, assembly and decorating advantages by cleaning, etching and functionalizing surfaces. A wide range of characteristics of the surface could be achieved: roughness, wettability modificationshydrophilicity or hydrophobicity, surface charge, altering the surface energy, biocompatibility, antimicrobial activity, reactivity.

\section{SURFACE ENGINEERING}

The surface properties of treated materials depend on several factors between which are:

a) The surface chemistry, morphology, and mechanical properties that are very important to the adhesion, film formation process, and the resulting film properties.

b) The bulk material also has influence on the performance of the surface.

c) The last but not less important is the way of fabrication and treatment of the surface.

Each process for surface engineering of materials has own characteristics and particular applications. There are cases when surface treatment modify the substrate surface prior film deposition; or there are other cases, when surface modification is used to change the properties of an overlay coating. The resulting surface layer or coating 
could have different structure and morphology: from single crystal to amorphous, porous or less porous, thin or thick coat [1-6].

Modification of the surface could be achieved by:

1) an overlay process - coating - a material is added to the surface of the underlying substrate material,

2) a surface modification process - process that changes the properties of the substrate's surface but, the same material is still existing on the surface.

3) A diffusion processes (nitriding, plasma nitriding,) - is a mixture of the previous two abovementioned modifications. They are thermochemical diffusion processes in atmosphere of N2, $\mathrm{C}$ or $\mathrm{O} 2$ where these atoms penetrate in the structure of the basic material.

Table 1 - List of coating processes [4]

\section{Classification of thin film and coating processes}

The properties of the films are affected by the properties of the underlying substrate material and it can vary through the film thickness.

Generally, the term "thin film" is applied to layers with thicknesses on the order from few atomic layers to a microns. Thin film is the general term used for coatings that are used to modify and increase the functionality of a bulk surface or substrate. They are used to protect surfaces from wear, improve lubricity, improve corrosion and chemical resistance, and provide a barrier to gas penetration. In many cases thin films do not affect the bulk properties of the material. They can, however, totally change the optical, electrical transport, and thermal properties of a surface or substrate, in addition to providing an enhanced degree of surface protection.

\begin{tabular}{|c|c|c|c|}
\hline Atomistic deposition & $\begin{array}{l}\text { Particulate } \\
\text { deposition }\end{array}$ & Bulk coatings & Surface modification \\
\hline $\begin{array}{l}\text { Electrolytic } \\
\text { environment }\end{array}$ & Thermal spraying & Wet processes & Chemical conversion \\
\hline Electroplating & Plasma spraying & Painting & Electrolytic \\
\hline Electroless plating & D-gun & Dip coating & Anodization (oxide) \\
\hline Fused salt electrolysis & Flame spraying & $\begin{array}{l}\text { Electrostatic } \\
\text { spraying }\end{array}$ & Fused salts \\
\hline Chemical displacement & Fusion coatings & Printing & Chemical-liquid \\
\hline Vacuum environment & Thick film ink & Spin coating & Chemical vapor \\
\hline Vacuum evaporation & Screen printing & Cladding & Thermal \\
\hline Ion beam deposition & Jet printing & Explosive & Plasma \\
\hline Laser ablation & Enameling & Roll bonding & Leaching \\
\hline $\begin{array}{l}\text { Molecular beam } \\
\text { epitaxy }\end{array}$ & Electrophoretic & Overlaying & Mechanical \\
\hline Cathodic arc & Impact plating & Weld coating & Shot peaning \\
\hline $\begin{array}{l}\text { Vacuum polymer } \\
\text { deposition }\end{array}$ & & & Thermal \\
\hline Plasma environment & & & Surface enrichment \\
\hline Sputter deposition & & & Diffusion from bulk \\
\hline $\begin{array}{c}\text { Activated reactive } \\
\text { evaporation }\end{array}$ & & & Sputtering \\
\hline Cathodic arc & & & Ion implantation \\
\hline Plasma polymerization & & & Self-assembly \\
\hline Ion plating & & & \\
\hline \multicolumn{4}{|l|}{$\begin{array}{l}\text { Chemical vapor } \\
\text { environment }\end{array}$} \\
\hline \multicolumn{4}{|l|}{ Plasma enhanced } \\
\hline \multicolumn{4}{|l|}{ Atomic layer } \\
\hline \multicolumn{4}{|l|}{ deposition } \\
\hline \multicolumn{4}{|l|}{ Reduction } \\
\hline \multicolumn{4}{|l|}{ Decomposition } \\
\hline \multicolumn{4}{|l|}{ Spray pyrolysis } \\
\hline Liquid phase epitaxy & & & \\
\hline
\end{tabular}


In a summary, thin films offer a big potential due to the following aspects:

- creation of entirely new and revolutionary products

- solution of previously unsolved engineering problems

- improved functionality of existing products; engineering, medical, and decorative

- production of nanostructured coatings and nanocomposites

- conservation of scarce materials

- ecological considerations - reduction of effluxent output and power consumption [4].

Thicker deposits are usually called coatings or painting. A substance applied to other materials to change the surface properties, such as color, gloss, resistance to wear or chemical attack, improve permeability, lubricity, without changing the bulk properties is a coating material. Surface coatings include materials like, paints, varnishes, enamels, oils, greases, waxes, concrete, lacquers, powder coatings, metal coatings...

There is no accurate classification of the coating processes. Different authors classified them in various groups and often there is an overlap of process mechanisms, establishment of hybrid deposition processes, etc... In general, every property of the thin film/coating depends on deposition process and not all processes produce materials with the same properties. Namely, microstructure, surface morphology, tribological, electrical, and optical properties of deposited film are all controlled by the deposition process.

In general, categorization of thin film and coating deposition could be presented as (table 1):

1. atomistic growth,

2. particulate deposition,

3. bulk coating,

4. surface modification.

Each process has its advantages, disadvantages and particular applications. In some cases surface modification processes can be used to modify the substrate surface prior to depositing a film or coating.

In this paper the special emphasize is given to PVD technology and its application for polymer science for surface modification.

\section{PHYSICAL VAPOR DEPOSITION (PVD) PROCESSES}

The application of PVD techniques ranges over a wide variety of applications from decorative, to high temperature superconducting films. A very large number of inorganic materials-metals, alloys, compounds, and mixtures as well as some organic materials, like polymers, can be deposited using
PVD technologies. Nowadays, PVD is used to form multilayer coatings, gradient-depositions, or very thick deposits [1].

PVD processes include a wide range of vaporphase technologies. In general, PVD is used to describe variety of methods to deposit thin solid films by the condensation of a vaporized form of the solid material onto various surfaces. Namely, PVD process involves physical ejection of material as atoms or molecules and condensation and nucleation of these atoms onto a substrate. The vaporphase material can consist of ions or plasma and is often chemically reacted with gases introduced into the vapor, called reactive deposition, to form new compounds. The thicknesses of deposited layers could be from few nanometers to thousands of $\mathrm{nm}$ [4].

\section{Basic steps of PVD process}

Every PVD process can be defined by three basic steps:

(1) generation of the deposition or vapor-phase species: material can be converted to a vapor phase by evaporation, sputtering, or chemical vapors and gasses.

(2) transport of the species to the substrate: transport of vapor species from the source to the substrate can occur under line-of-sight, thermal scattering, or molecular flow conditions (without collisions between atoms and molecules). Alternatively, if the partial pressure of the metal vapor and/or gas species in the vapor state is high enough for some of these species to be ionized (by creating a plasma), there will be a large number of collisions in the vapor phase during transport to the substrate.

(3) film deposition on the substrate: once the atoms or molecules are deposited, the film nucleates on the substrate and grows by a number of processes. Microstructure and composition of the film can be modified by bombardment of the growing film by ions from the vapor phase, resulting in sputtering and recondensation of the film atoms and enhanced surface mobility of the atoms in the near surface and surface of the film [1, 4].

All processes are characterized by two sets of parameters:

i. plasma that includes the electron density, electron energy, and ion distribution, and

ii. process parameters -evaporation/sputtering rate, gas composition, pressure, gas flow rate, substrate bias, and temperature.

\section{Categorization of PVD processes}

The main categories of PVD process are [3]:

a. vacuum deposition (evaporation),

b. sputter deposition, 
c. arc vapor deposition, and

d. ion plating.

Vacuum deposition is a PVD process where material from a thermal vaporization source comes to the substrate with little or no collision with gas molecules in the space between the source and substrate.

Sputter deposition or just sputtering is deposition of particles vaporized from a surface "target" by the physical sputtering process. This is a nonthermal vaporization process where surface atoms are physically ejected from a solid surface by momentum transfer from an atomic-sized energetic particle that bombard the surface (usually it is a gaseous ion, accelerated from a plasma). Generally, the source to-substrate distance is short compared to vacuum deposition. Sputter deposition can be performed by energetic ion bombardment of a solid surface (sputtering target) in a vacuum using an ion gun or low pressure plasma where the sputtered particles suffer few or no gas phase collisions in the space between the target and the substrate.

Arc vapor deposition uses a high current, low voltage arc to vaporize a cathodic electrode or anodic electrode and deposit the vaporized material on the substrate. The vaporized material is highly ionized and usually the substrate is biased so as to accelerate the ions ("film ions") to the substrate surface. Usually, arc vapor deposition is used to deposit hard and decorative coatings.

Ion plating or ion vapor deposition, utilizes periodic bombardment of the depositing film by atomic-sized energetic particles to modify and control the properties of the depositing film.

\section{Non-PVD Processes}

There are other thin film deposition technologies called non-PVD deposition technologies that can be used for particular applications. They are:

a) Chemical Vapor Deposition (CVD) and plasma enhanced CVD (PECVD)

b) Electroplating, Electroless Plating, and Displacement Plating

c) Chemical Reduction

Plasma-based chemical vapor deposition involves chemical reactions on the substrate surface and most likely reactions in the gas phase as well. The treatment temperature in this process is usually higher in order to enable chemical reactions. In general, this process allow the deposition of metals, alloys, ceramic, and polymer thin films.

\section{Hybrid processes}

Hybrid deposition processes are gaining new applications because a single deposition process may not be able to achieve the optimum coating performance for multilayer and nanocomposite thin films. The deposition process must be chosen to fit the required properties and final application. Hybrid processes usually combine the best attributes of each PVD and/or non-PVD like, CVD process $[1,4]$.

Novel surface engineering techniques and hybrid processes are now being used for creating advanced thin film materials and structures that were not possible with conventional techniques decades ago. They are used in many areas of technology, automotive, aerospace, power, chemical, electronic, biomedical, textile, petrochemical, machine tools, and construction industries. Almost all types of materials, including metals, ceramics, polymers and composites, can be treated or deposited onto similar or dissimilar materials.

\section{POLYMERS AS SUBSTRATES TO BE SURFACE ENGINEERED}

Although progress in polymer science and engineering in the last decades is ground-breaking, opportunities are abundant for creating new polymeric materials and modifying the existing polymers for new applications.

Scientific understanding for polymeric materials is going towards design on the molecular scale in order to meet needs of advanced technology and assuring their new applications in medicine, biotechnology, electronics, communications, aerospace... But, nowadays, surface engineering of polymers adds novel set of surface properties of the polymers that is a big challenge and very attractive as well.

In the text below is given brief description of polymer in general. A polymer is a large molecule formed by bonding together numerous small molecular units - monomers which are based on carbon-hydrogen atoms that may or may not contain other elements such as nitrogen, oxygen, metals, etc. In polymer structure, many bonds are formed which have various strengths, orientations, and lengths between atoms and functional groups. These bonds as well as chemical composition and physical state of the polymer determine the general behavior of polymers. Namely, the chemical properties of the polymer surface depend on the functional groups present on the surface and may depend on the vapor (or environment) in contact with the surface. The mechanical properties of the surface region are in tight relationship of the amount and type of crosslinking of the polymer material. Often the near-surface region of a polymer material has quite different mechanical properties from the bulk of the material $[3,5]$.

On the other hand, surface energy and surface tension result from non-symmetric bonding of the surface atoms/ molecules in contact with a vapor, measured as energy per unit area. Surface energy 
is an important indicator of surface contamination and the composition of a polymer surface. In most cases, surface energy should be changed (increased) in order to deposit other material (film) on polymers.

\section{Surface modifications of polymers}

Surface engineering of polymers is attractive from commercial and academic view. Determined surface engineering starts with proper modification or activation of polymer surface. There are many methods for modification of polymer surface, like, wet chemical, flame, physical abrasion, ion beam treatment, plasma treatments, additives, etc... These treatments in general produce certain chemical functionalization of the polymer surface. Usually, the change of the surface properties is targeted towards good bonding with next deposited layer(s).

In general, polymers are with (very) low surface energy that make them unable for direct coating or deposition of similar or dissimilar material. In order to improve this issue, a good adhesion between polymer and deposited film(s) should be made, or in other words to find out the way to increase the surface energy of the polymers. But, high surface energy alone does not guarantee good adhesion; however, the versatility of the process enables tailoring of the surface chemistry for optimal adhesion or superior product performance $[2,6]$.

Substrate preparation is critical and the surface morphology and composition of a substrate can be modified by diffusion, plasma treatment, self-assembly, chemical etch, and reactive heat treatment. The resulting surface will influence the properties, structure, adhesion, and surface texture of a thin film.

Surface preparation includes not only surface modification to change the properties of the surface, but also surface cleaning as well, which is the reduction of surface contamination to an acceptable level. Cleaning is used so that desirable processing and film/coating properties can be obtained. Practically, a 'clean' surface is one that contains no significant amounts of undesirable material; thus a clean surface depends on the requirements.

Generally, the most frequent contaminants are hydrocarbons that can cause a low nucleation density of the depositing film on a surface, or poor overall adhesion of a film to a surface. Local contamination (film or particle) can result in locally poor adhesion of a film to a surface giving pinholes in the film.

The surface "activation" ("functionalization") is the temporary increase of the chemical reactivity of a surface, usually by changing the surface che- mistry. The effect of many surface activation treatments on polymers degrades with time, so the activated surface should be used within a shorter time period after activation.

There are several processes for surface modification of polymers, such as: plasma activation, corona activation, flame activation, electronic charge sites and dangling bonds, surface layer removal. Briefly, they are going to be explained below $[1,4]$.

a) Plasma activation is an effective and one of the most used method of modifying a wide variety of polymeric and elastomeric surfaces. The plasma process is not operator-sensitive. Its significant characteristics are: reproducibility, cleanliness, and the ability to more consistently provide high reliability bonds.

For plasma treatment of polymer surfaces usually are used inert or reactive gas(es). They are used to activate polymer surfaces either as a separate process or in PVD chamber. Oxygen or nitrogen plasmas are usually used for activating the surfaces. Oxygen plasma treatment forms carbonyl groups on the surfaces (gives an acidic behavior). Nitrogen or ammonia plasma treatments make the surfaces more basic, due to the establishment of amine and imine groups to the surface. But, other gasses are not excluded in this process like, ammonia, air, halogens, for cleaning surface contaminants, microablation of the surface, and substituting various chemical groups onto the polymer chain.

Surfaces may be treated in inert gas plasmas as well. In the early studies of plasma treatment with inert plasmas, plasma contamination probably resulted in oxidation. The activation that occurs in an inert gas plasma is probably from UV radiation from the plasma, causing bond scission in polymers.

Activating plasmas have three competing molecular reactions that alter the plastic simultaneously:

1. Ablation (microetching) - removal by evaporating surface material either for cleaning or for creating surface topography,

2. Cross-linking - creating covalent bonds or links between parallel long molecular chains,

3. Substitution - the act of replacing atoms in the molecule with atoms from the plasma.

Plasma treatment of polymer surfaces results in surface texturing that make changes in surface chemistry due to changes in termination species. In this way the improved adhesion strengths can be attributed to mechanical interlocking. But, if surfaces are over-treated with plasmas, creating a weakened near-surface region and reducing the film adhesion. Care must be taken to ensure that 
the surface preparation processes do not change the surface in an undesirable or in an uncontrolled manner. [2,6]

b) Corona Activation is established in ambient pressure air when a high voltage/high frequency potential is applied between two electrodes, one of which has a coating of material with a dielectric constant greater than air. If the surfaces have a dielectric constant less than air or if there are pinholes in the coating, spark discharges occur.

c) Flame Activation of polymer surfaces is accomplished with an oxidizing flame. In the flame, reactive species are formed which react with the polymer surface, creating a high surface energy. The surface activation is not as great as with corona treatments but does not decrease as rapidly with time as does the corona treatment. This treatment is often used in "off-line" treatment of polymers for ink printing.

d) Electronic Charge Sites and Dangling Bonds -an activation of a surface can be accomplished by making the surface more reactive without changing its composition. This is often done by generating electronic charge sites in glasses and ceramics or bond scission that create "dangling bonds" in polymers. Activation of polymer surfaces can be accomplished using UV, X-ray, electron, or ion irradiation.

e) Surface Layer Removal of oxide layer from metal surfaces is an activation process if the surface is used before the oxide reforms. In electroplating, the oxide layer can be removed by chemical or electrolytic treatments just prior to insertion into the electroplating bath. Such activation is used for plating nickel-on-nickel, chrome-on-chrome, gold-on-nickel, silver-on-nickel, etc...

\section{CASE STUDIES - EXAMPLES OF PVD SURFACE ENGINEERED POLYMERS}

Plasma Doo - Center for plasma technologiesSkopje, Macedonia, has a quite long tradition in surface engineering of different types of materials. One of them is class of polymeric materials that were surface engineered in its facility. Figure 1 presents PVD chamber in Plasma facility.

In the text bellow is given a short overview of different functional coating(s) on a variety of polymers. Functional coatings were deposited for different purposes, such as: resistance to wear abrasion, ageing, decorative and esthetic appearance, better mechanical properties on the surface, improve of the barrier properties, enhanced optical performance, metal-like reflectors based on polymer, etc... Combination of processes for preparation of the surfaces as well as for deposition (explained in Section 4) are applied for these case studies.

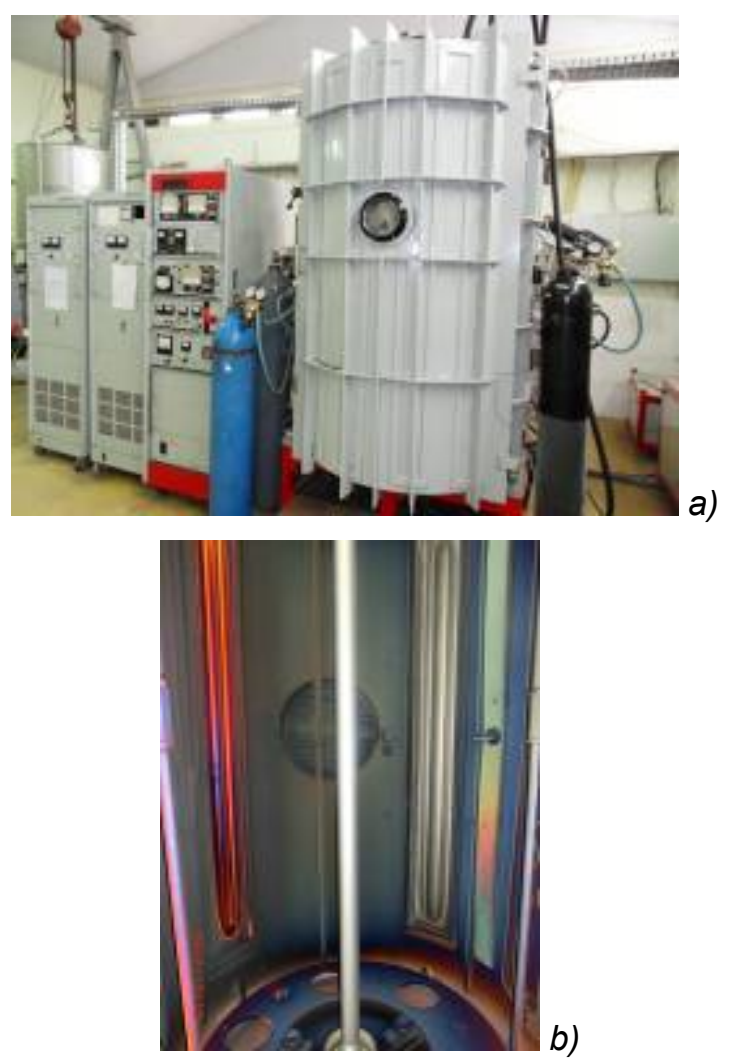

Figure 1 - PVD chamber: a) chamber with control boards for operation of the chamber, $b$ ) inner view of the targets inside the chamber

\section{Acrylo-Butadiene-Styrene (ABS)}

$A B S$ valve samples (Figure 2) were coated with variety of metal based depositions such as: $\mathrm{Ti}, \mathrm{TiN}$, $\mathrm{TiC}$ or $\mathrm{Ti}-\mathrm{TiO} 2$ in order to increase their mechanical performance.
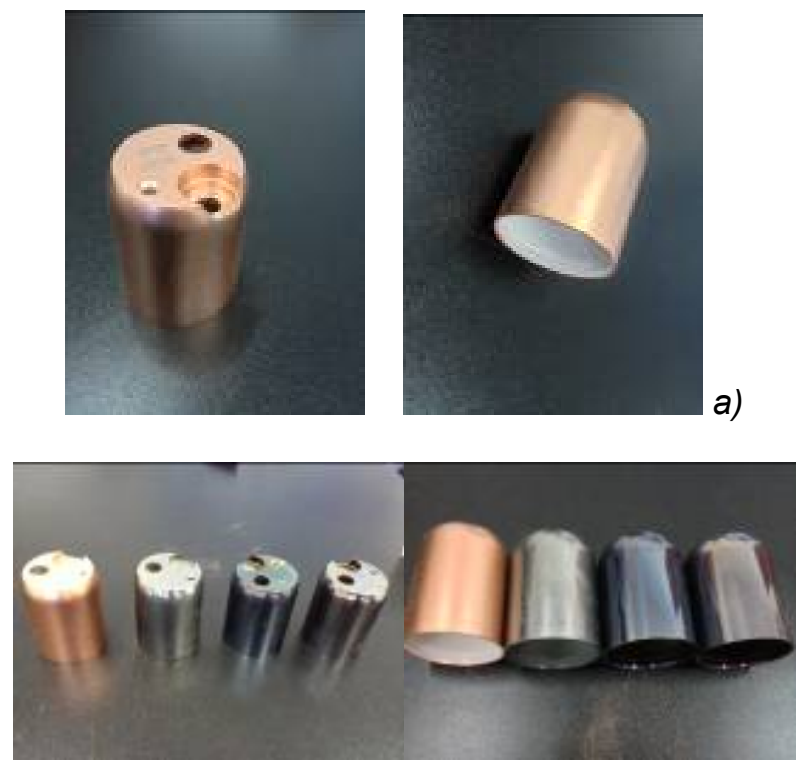

b)

Figure 2 - PVD coated ABS samples: a) Cu-coated, b) TiN, Ti , Ti/TiO2, TiC coatings 


\section{Polyetherimide (Ultem)}

In Figure 3 are shown dental tools made from ULTEM or polyetherimide. Ti- coating was deposited on them for improving their mechanical properties.

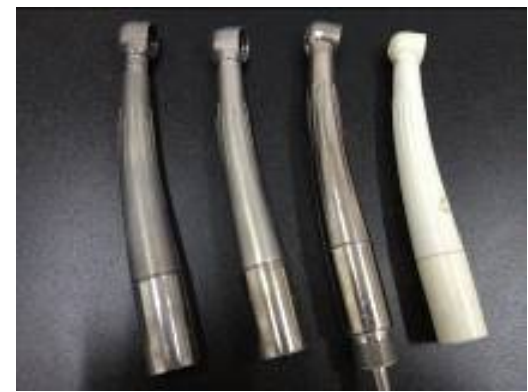

Figure 3 - Polyetherimide dental tools. Ti-coated (the first three samples from the left side) vs. uncoated tool (one sample on the right side)

Polyethelyne terephthalate (PET)

Figure 4 presents some samples made of PET and coated for different purposes.

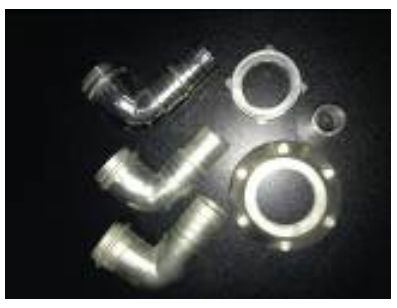

a)

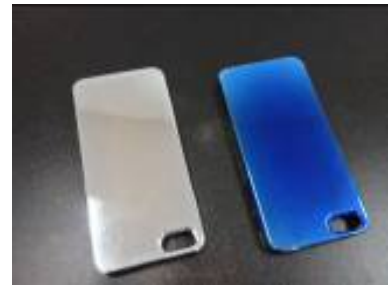

b)
Figure 4 - PET samples coated with: a) Ti- PVD deposited coatings for different purposes, b) $\mathrm{TiO}_{2}$ deposited coatings for decorative purpose

\section{Epoxy - carbon composites}

Within the project EUREKA ,,Development Of New Actuators, Materials And Technology For The Production Of Advanced Pneumatic And Hydraulic Valves,, (E!4548 - DE_AMATECH 2009), Plasma team performed the ability to deposit functional coatings based on Ti/TiN and $\mathrm{Ni} / \mathrm{Ti} / \mathrm{TiN}$ over composite plates based on epoxy-carbon fibers (Figure 5). Increase of wear resistance of valves was achieved. [7]

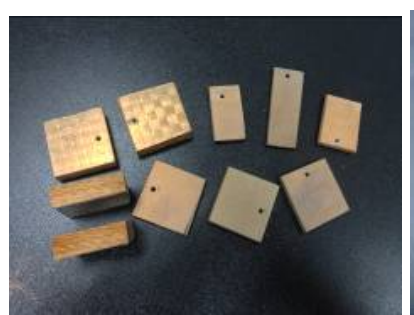

a)

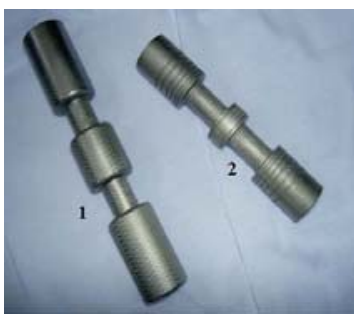

b)
Figure 5 - a) Coated epoxy-carbon composite samples with different alloyed depositions based on Ti-Ni. b) Prototypes of pneumatic (1) and hydraulic (2) pistons with hard surface coatings [7]

\section{Current projects}

Plasma team currently is working on several EU and national projects that deal with surface engineering on polymers. Some of them will be briefly presented here due to the fact that they are still running.

\section{Development of multilayered optical coating on PC substrate}

Within POLYSOL FP7 project, Plasma developed selective multilayered coating on polycarbonate (PC) substrate and PC-graphite composite material as well (figure 6). The goal of these coatings deposited by PVD technologies and use of different metal and non-metal targets in different working gasses was to obtain an optimal optical performance of the tandem: substrate + stack of coatings. [8]

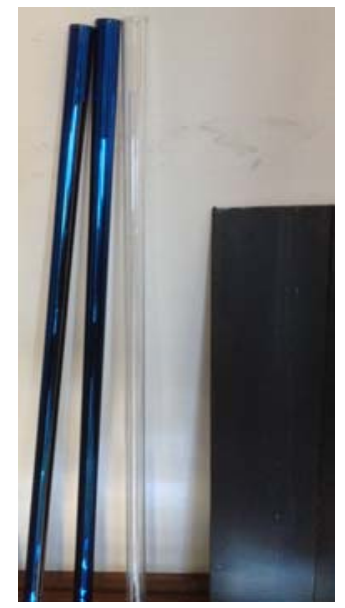

Figure 6 - Multilayered selective coating on PC tubes (on the left: two coated tubes vs. uncoated tube) and coated $P C$ plate (on the right)

Development of metal reflector on PET polymer substrates

Composol is other project where Plasma is one of the participant. Namely, the role of Plasma team in this project is developing of metal reflective material like, $\mathrm{Al}$ or $\mathrm{Ag}$, on different polymer substrates. One of them is polyethylene terephthalate (PET) substrate (Figure 7).
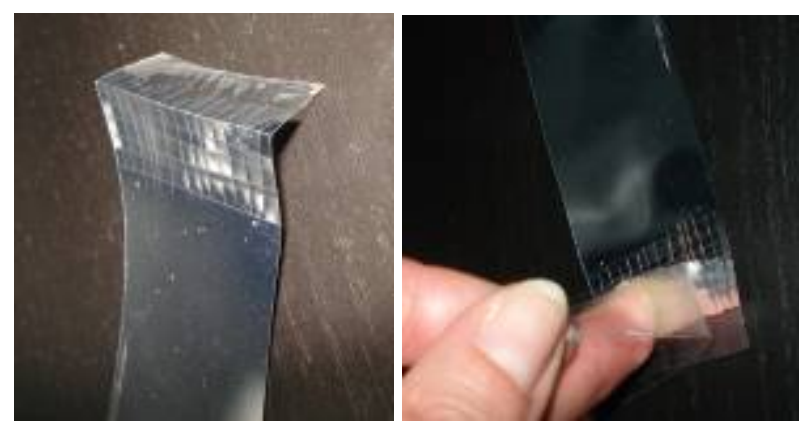

Figure 7 - Ag-deposited PET foils 
The deposition process and working parameters were adjusted in PVD chamber in order to match the best appearance and optical characteristics of the mirror-like polymer reflector [9].

Development of barrier coating on biodegradable polymer substrates

The third EU FP7 project is Dibbiopack Plasma team is working on establishing barrier coatings on biodegradable plastics such as cellophanes and PLA polymer composites doped with different nanodopants. The purpose of such coated biodegradable polymer composition is application of them in area of packaging of food, cosmetics, and pharmaceutics. The barrier coatings are based on PVD deposition from Si-target in different gas atmosphere like, O2 or N2. [10]

More details of these projects will be additionally given after finalizing of the projects.

\section{REFERENCES}

[1] Bunshah R. F, Handbook of hard coatings, Noyes Publication, 2001.

[2] Tracton A. A., Coatings technology handbook, Taylor \& Francis Group, LLC, 2006.
[3] Mattox D.N., Handbook of Physical Vapor Deposition (PVD) Processing, Elsevier Inc., 2010.

[4] Martin P.M., Thin Film Coatings, III-rd Ed., Elsevier Inc., 2010.

[5] Ryntz R. A, Yaneff P.F., Coatings of Polymers and Plastics, Marcel Dekker Inc., 2003.

[6] Wells R. K., Surface engineering of polymers, Durham University, PhD Theses, 1994.

[7] Bogoeva-Gaceva G. et. al., New Materials for Production of Advanced Pneumatic and Hydraulic Valves, The International Conference on Composite Interfaces, Interface 21, Kyoto, Japan, 2012.

[8] Development of a modular, all-POLYmer SOLar thermal collector for domestic hot water preparation and space heating, http://www.fp7-polysol.eu/, PolySol FP7 project, 2010-2012.

[9] Fibre Reinforced Composite Reflectors for Concentrated Solar Power Plants, Composol FP7 project, 2011-2013.

[10] Development of injection and blow extrusion molded biodegradable and multifunctional packages by nanotechnology: improvement of structural and barrier properties, smart features and sustainability, http://www.dibbiopack.eu/, Dibbiopack FP7 project, 2012-2016.

\title{
IZVOD
}

\author{
POVRŠINSKI INŽENJERING NA POLIMERIMA \\ - STUDIJA SLUČAJA: PVD PREVLAKE NA POLIMERIMA
}

Površinski inženjering je deo nauke o materijalima - promena svojstva površine i subpovršinskog regiona prema zahtevu i potrebi. Mnoštvo naprednih karakteristika površine supstrata kao što su fizičke, hemijske, mehaničke, električne, optičke, magnetne, otpornost trenja, otpornost koroziji, itd., moguće je promeniti i modifikovati. Hemijska, morfološka i mehanička površinska svojstva mogu biti od velike važnosti za adheziju pri formiranju filma i krajni rezultat - svojstva površinskog filma.

$U$ ovom radu autori predstavljaju fizičko isparavanje i nanošenje (physical vapour deposition -PVD) kao metod za površinsku modifikaciju i nanošenje prevlake na polimerne materijale. Metoda je čisti ekološki postupak koji može da se vodi u jednom kontinualnom ciklusu-procesu PVD komore. Čišćenje polimerne površine, aktivacija, modifikacija i nanošenje prevlake je u okviru jednog kontinualnog procesa. Na kraju, veliki broj eksperimenata modifikacije i nanošenja na određenom broju polimera je prikazan u ovom radu. Predstavljena su vlastita istraživanja na sučaju (case studies) aktivacije, modifikacije i nanošenja prevlake na birane polimere za ciljane primene, gde osnovni polimeri nisu mogli da odgovore na industrijske zahteve.

Ključne reči : površinski inžinjering, fizičko isparavanje i nanošenje, polimeri

Pregledni rad

Primljeno za publikovanje: 20. 10. 2013.

Prihvaćeno za publikovanje: 26. 12. 2013. 